\title{
The Effectiveness of the Role of the Village Government in Suppressing Dropout Rates in Pattongko Village
}

\author{
Sofyang $^{1}$, Syamsiah Hasyim ${ }^{2}$ \\ 1,2, Universitas Muhammadiyah Sinjai \\ Email: sofyanalsinjai@gmail.com
}

\begin{abstract}
Education is essentially an effort to facilitate students to be able to solve problems in life that they will face in the future. This research aims to determine the effectiveness of the role of the village government in reducing the dropout rate in Pattongko Village, Sinjai Tengah District, Sinjai Regency, and the factors that cause school dropout. This research uses qualitative research. The data collection techniques used were interviews, observation, and documentation. The data analysis technique used is data collection, data reduction, data presentation, decision making (verification). The results of this study state that the effectiveness of the role of the village government in suppressing the dropout rate in Pattongko Village, Sinjai Regency, related to its role as a motivator, facilitator, and mobilizer tends to be effective, this can be seen from the decrease in the dropout rate every year. this is due to the concern of the local government, especially the village government together with parents and the community. The factors causing dropping out of school in Pattongko Village in this study consisted of four factors, namely the Child itself, the Economic Condition, the distance between the house and the school which was far away, and the parents' lack of understanding of the importance of education.
\end{abstract}

Keywords: Effectiveness, village governance, dropping out of school

\section{INTRODUCTION}

Education is essentially an effort to facilitate students to be able to solve problems in life that they will face in the future. Of course with the hope that students can become better, can develop their potential, and be useful for their environment (Arhas, 2018; Fransiska, 2016; Saleh, Arhas, et al., 2019; Saleh, Jamaluddin, et al., 2019). According to (Undang-Undang Nomor 6 Tahun 2014 Tentang Desa.) states that improving the quality of government and village communities through education, training, and counseling; Thus, the article explains that one of the duties of the village government is to increase human resources (HR) through education development. Increasing human resources will affect people's lives so that they can be more advanced and developed (Bagheri, 2016; Searcy et al., 2016; Sparkes \& Miyake, 2000). Because with fostering public education, knowledge, and technology can be obtained to be smart, skilled, and ethical, because, with intelligence, skills, and ethics, a person will be able to face and solve all kinds of life challenges, because with science and technology life is getting easier and with life, ethics will be more focused (Undang-Undang Nomor 6 Tahun 2014 Tentang Desa). Therefore, what must be a priority in fostering community life is the education sector (Ikhsan et al., 2019; Sirait et al., 2019).

The measure of the success of coaching and development in an area is the success in the field of education (Elacqua \& Marotta, 2020; Sung, 2017; Wang et al., 2020). Therefore, 
one indicator of the success of community development is the low dropout rate in the region. To achieve a higher level of social welfare, the learning society must become a culture in society. Therefore, what must be a priority in the development of community life is the education sector.

However, these efforts have not been able to prevent dropouts. This is reflected in the results of research conducted by the author in Pattongko Village. That the dropout rate was still high, starting from the lower level to the upper secondary level from 2018 to 2020 . Namely: 1) SD / MI, 20 students dropped out of school, 20 SMP / MTs, 343 students dropped out of school, 5 people, SMA / SMK / MA with 228 students, 56 dropping out of school. From these data, it shows that the number of school dropouts from the three levels shows a very high number, especially SMA level.

From the problems that occurred above in Pattongko Village, Sinjai Regency, the researcher will use the theory of (Hermansyah, 2015) about the Role of Village Government, namely: Motivator, Facilitator, and Mobilizer.

\section{METHOD}

In this research method, researchers used a qualitative descriptive research method according to (Sugiyono, 2017). Data sources are (1) Primary data, namely data obtained after conducting a series of interviews and seeing directly with school dropouts, school principals, namely village heads, community leaders, parents of children who have dropped out of school,; (2) Secondary data, namely supporting data obtained from literature and articles related to the issues discussed regarding the effectiveness of the role of the village government in reducing dropout rates. Data collection techniques are interviews and observation and documentation study. The model or qualitative data analysis technique in this research is: data reduction, data presentation, and conclusion. Data reduction is collecting data, summarizing and selecting the main things, focusing on what is important. Presentation of data, presenting data with narrative text, to plan further research work based on what has been understood. Namely as organizing data that has been reduced. In presenting this data, the researcher made an effort to construct a pattern of relationships from all existing data so that the data was easier to understand. Conclusion/verification is drawing conclusions that have been supported by valid and consistent evidence in the research field.

\section{RESULT AND DISCUSSION}

\section{Pattongko Village Leadership}

The leadership in Pattongko Village, starting from 1960 to 2020, consisted of 13 village heads. This proves that for years, leaders with different leadership styles in carrying out their duties and responsibilities, as well as their respective roles.

According to (Ardinal Barlan \& M. Kolopaking, 2015) The village government as a local leader can influence the surrounding community as much as possible. The magnitude of the influence of the actions is influenced by the role they show in society. The leader's ability to invite, guide, and motivate citizens in various government affairs in rural areas is the main ability that must be possessed. The leader must be close to the community and know the various problems faced so that the problems that occur within the scope of his government the leader must be able to overcome and provide solutions. 


\section{Number of Schools}

The number of schools in Pattongko village is presented in table 1:

Table 1.

Pattongko Village School.

\begin{tabular}{cll}
\hline Number. & \multicolumn{1}{c}{ School Name } & \multicolumn{1}{c}{ Address } \\
\hline 1 & SDN 64 Manubbu & Manubbu Hamlet \\
2. & SDN 112 Sattulu & Sompong Hamlet \\
3. & Miftahusshafah Tapillasa & Tpillasa Hamlet \\
4 & MI Nurul Falah Tangkulu & Tangkulu Hamlet \\
5 & MTs Muhammadiyah Pattongko & Manubbu Hamlet \\
6 & SMA Muhammadiyah Pattongko & Manubbu Hamlet \\
\hline
\end{tabular}

Source: 2020 Village Office Administration

The number of schools in Pattongko village is 6 schools. Consisting of 4 SD, 1MTs, and 1 SMA. Based on the data obtained by the researcher, it is described in table 2-4:

Table 2.

Pattongko Village School Dropout Rate in 2018

\begin{tabular}{clccc}
\hline Number & \multicolumn{1}{c}{ School } & $\begin{array}{c}\text { The number of } \\
\text { students }\end{array}$ & Dropout & Percentage \\
\hline 1. & SD/MI & 402 & 8 & $1.9 \%$ \\
2. & SMP/MTs & 124 & 1 & $0.8 \%$ \\
3. & SMA/SMK/MA & 79 & 21 & $26.5 \%$ \\
\hline & Total & 605 & 30 & $4.9 \%$ \\
\hline
\end{tabular}

Source: 2020 Village Office Administration

Table 3.

Pattongko Village School Dropout Rate in 2019

\begin{tabular}{clccc}
\hline Number & \multicolumn{1}{c}{ School } & $\begin{array}{c}\text { The number of } \\
\text { students }\end{array}$ & Dropout & Percentage \\
\hline 1. & SD/MI & 393 & 9 & $2.29 \%$ \\
2. & SMP/MTs & 113 & 4 & $3.53 \%$ \\
3. & SMA/SMK/MA & 76 & 15 & $19.73 \%$ \\
\hline & Total & 582 & 28 & $4.81 \%$
\end{tabular}

Source: 2020 Village Office Administration 
22 Jurnal Administrare: Jurnal Pemikiran Ilmiah dan Pendidikan Administrasi Perkantoran Volume 8 Issue 1, January-June 2021. Pages 19-26

Table 4.

Pattongko Village School Dropout Rate in 2020

\begin{tabular}{llccc}
\hline Number & \multicolumn{1}{c}{ School } & $\begin{array}{c}\text { The number of } \\
\text { students }\end{array}$ & Dropout & Percentage \\
\hline 1 & SD/MI & 399 & 3 & $0,75 \%$ \\
2 & MTS & 106 & - & $0,00 \%$ \\
3 & SMA & 73 & 20 & $27,39 \%$ \\
\hline & Total & 578 & 23 & $3,97 \%$ \\
\hline
\end{tabular}

Source: 2020 Village Office Administration

From table 2, table 3, and table 4 it has been shown that in 2018 the dropout rate was 30 people, while in 2019 there were 28 people. This has proven that there has been a decrease in dropout rates at the elementary to high school levels in that year.

Table 5.

Dropout Rate at the Hamlet Level

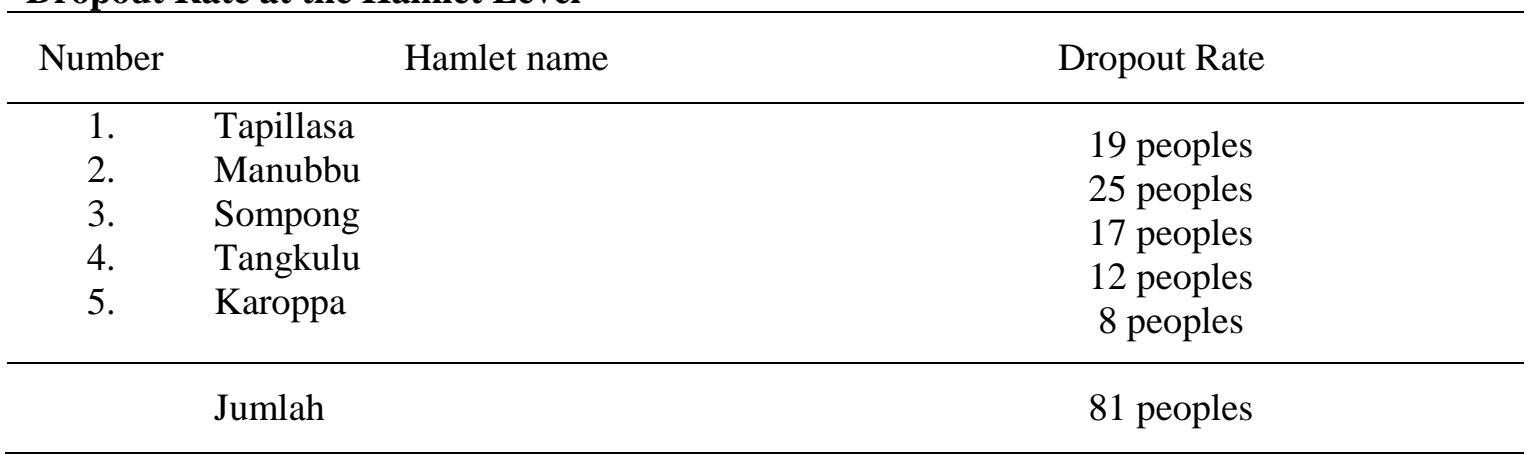

Source: Processed research data

From the data obtained by researchers in the field of school dropouts in 2018, there were 30 people. there are 5 hamlets in Patongko Village

Table 6.

Comparison of School Dropout Rates in 2018-2020

\begin{tabular}{ccc}
\hline The 2018 year & The 2019 year & The 2020 year \\
\hline 30 & 28 & 23
\end{tabular}

Source: Processed research data

Based on the data from the Dropout Rate above, it can be concluded that in the last 3 years there has been a decrease in the dropout rate from 2018-2020. This is due to the involvement/concern of the Village Government, Community, and Parents. So that the dropout rate in Pattongko Village is decreasing. 


\section{Discussion}

According to (Sugiman, 2018) that the village government as the administrator of government is carried out by the village head who is assisted by village officials as an element of village administration. In the life of a state, the government is very much needed to regulate the people, protect the people, and fulfill the people's needs because the nature of the state is coercive, monopolistic, and includes both. With a government, all territories and boundaries can be controlled and monitored and can be easily regulated. Each region has its government and governmental apparatus starting from the village, sub-district, sub-district, district, province, and central government. This opinion is in line with the opinion of Bayu Suriningrat (Aksan et al., 2018) The Village Head is the sole ruler in the village government, together with his assistants and he is the village official in the implementation of village household affairs, besides that he carries out government affairs. (Hermansyah, 2015) in the journal The Role of the Village Head in Village Development Implementation, namely as a motivator, as a facilitator, as a mobilizer.

\section{Role as a Motivator}

Message As a motivator is someone who motivates to achieve a goal so that the implementation of development runs as expected. The village government always provides motivation and input and support by encouraging government officials at the village office, apart from that the village head is a leader who has a high sense of responsibility to the community, especially in suppressing the dropout rate. There is still a dropout rate every year. So, the village government must be active in overcoming this. The Village Government must strive so that in the future there will be no more people who do not enjoy education. As one of the roles of the village government is to motivate the community to increase community awareness of the importance of education in life.

Many sources are involved in suppressing dropout rates, one of which is community leaders who also take their role in this case by encouraging parents first and then to the younger generation to continue their education at every opportunity. Both at formal meetings and informal meetings. At a formal meeting held at a meeting at Auala, the Village office is used to explain the importance of education for children as well as at every informal meeting activity is also used by the Village Head and Community Leaders to explain the importance of education. This shows that the village government and community leaders have carried out their role as motivators, but only in the form of advice.

\section{Role as Facilitator}

The role as a Facilitator, namely the Village Government in suppressing the number of suppressing the Dropout Rate in Pattongko Village, the results of the research shows that what the village government is currently doing is by providing a certificate of being poor or unable to make it easier for these children to get scholarships and to get the Smart Indonesia Card (SIC) programmed by the government since the administration of Pak Jokowi and Muh. Amin.

A form of concern for the village government towards children who continue their education even though the village government has not provided assistance in the form of materials or in the form of funds for schoolchildren or school supplies for children to prevent or suppress the dropout rate in Pattongko Village, namely SIC. Regarding the use of new village 


\section{Jurnal Administrare: Jurnal Pemikiran Ilmiah dan Pendidikan Administrasi Perkantoran Volume 8 Issue 1, January-June 2021. Pages 19-26}

funds, it will be budgeted in the future APBDes. Some of the people at this time have benefited from the role of the government as a Facilitator, namely with the assistance of processing a certificate of disability and the Smart Indonesia Card. As a benefit to the community to help ease their burden, namely the cost of children's education.

Based on the data found by researchers through interviews and observations found in the field, it can be concluded that 27 students had been given a letter of incapacity by the village government, this was aimed at making it easier for them to get educational assistance at school.

There are two ways to administer SIC and a certificate of incapacity, namely the management carried out by the community directly and representatives by the school. With the same goal, namely to get education fee assistance. So in this case, apart from the village government, the school also plays an active role in reducing the dropout rate at schools in Pattongko Village.

\section{Role as a Mobilizer}

The role of the village government as a mobilizer is to move or invite the community to jointly take concrete actions, for example, the village government often tells village officials to encourage its citizens to care about education so that no more children drop out of school and children in the future can become capable children. improve his future.

According to (Aksan et al., 2018) several things need to be considered so that leadership can play a good role, among others. The main basis for leadership effectiveness is not the appointment or appointment, but the acceptance of others for the leadership concerned; leadership effectiveness is reflected in the ability to grow and develop; leadership effectiveness requires skills to read the situation; one's behavior is not just formed, but through growth and development; dynamic and harmonious organizational life can be created if each member is willing to complete his way of thinking and acting to achieve organizational goals.

\section{Factors that cause school dropout}

According to (Rahmawati et al., 2020) argued that the factors causing dropout were:

1. Internal factors, including:

a. From within, children dropping out of school because they are lazy to go to school because they feel inferior, cannot socialize with their school environment, are often ridiculed for not being able to pay school fees, influenced by various factors.

b. Because of the influence of friends, they were invited to play like a play station, until they often skipped classes and did not progress to the class, the achievement at school decreased and they were embarrassed to go back to school.

c. Children who are subject to sanctions because they are absent from school so that are subject to Drop Out.

2. External Factors

a. The state of the family's economic status.

b. Parents' attention, the relationship between parents is less harmonious. Apart from the above problems, there are important factors in the family that can cause children to drop out of school, namely: the economic situation of the family; educational background of father and mother; father's status in society and employment; the psychological social relationship between parents and between children and parents; the aspirations of 
parents about children's education, as well as their attention to children's learning activities; the size of the family and the people who play a role in the family. To solve the community the educational problems faced, especially the problem of dropping out of school, the government as a local leader must be close to the community and know the problems that occur within the scope of its government.

In Pattongko village, the factors for dropping out of school vary from each level, namely interviews with the village head and several community leaders and parents. Students said that children dropping out of school was mostly due to economic demands; of the child himself; lack of parental understanding of the importance of education; distance between home and school far apart.

The results of interviews with all school principals in Pattongko Village, consisting of 6 school principals, stated that "children quit school because the school is rather far away; from the child himself; economic conditions; lack of parental understanding of the importance of education.

Based on the results of research and observations from elements of village government, school principals, parents, and children dropping out of school, it can be concluded that the causes of children dropping out of school are: from the child himself; economic demands; lack of parental understanding of the importance of education; and the distance between home and school.

\section{CONCLUSION}

Based on the results of the study, it was found that the effectiveness of the role of the village government in suppressing the dropout rate was effective in terms of its role as a motivator, facilitator, and mobilizer. because of this, the dropout rate in Pattongko Village has decreased from 2018 to 2020. The factors that cause dropping out of school are mostly caused by the child's self, economic demands, and the lack of parental understanding of the importance of education and distance between far school homes.

\section{REFERENCES}

Aksan, H.Rekson, Limba, S., \& Tanzil. (2018). Peran Kepala Desa Dalam Meningkatkan Pembangunan Desa (Studi di Desa Baliara Selatan, Kabupaten Bombana) Oleh: Neo Societal, 3(1), 244-253.

Ardinal Barlan, Z., \& M. Kolopaking, L. (2015). Peran Paguyuban Dalam Pembangunan Kawasan Desa. Sodality: Jurnal Sosiologi Pedesaan. https://doi.org/10.22500/sodality.v2i2.9419

Arhas, S. H. (2018). Metode Pembelajaran Black Knight. Apa? Mengapa? dan Bagaimana? Jurnal Ad'ministrare, 5(2), 165-172.

Bagheri, J. (2016). Overlaps between Human Resources' Strategic Planning and Strategic Management Tools in Public Organizations. Procedia - Social and Behavioral Sciences, 230, 430-438. https://doi.org/https://doi.org/10.1016/j.sbspro.2016.09.054

Elacqua, G., \& Marotta, L. (2020). Is working one job better than many? Assessing the impact of multiple school jobs on teacher performance in Rio de Janeiro. Economics of Education Review, 78, 102015. https://doi.org/https://doi.org/10.1016/j.econedurev.2020.102015 
Fransiska, C. (2016). Pengaruh Kompetensi Profesional Guru terhadap Kualitas Proses Pembelajaran pada Paket Keahlian Administrasi Perkantoran Di SMK Negeri 1 Bungoro Kabupaten Pangkep. Jurnal Office, 2(2), 163-172.

Hermansyah. (2015). Peran Kepala Desa Dalam Pelaksanaan Pembangunan Kecamatan Tana Lia Kabupaten Tidung. Pemerintahan Integratif, 3(2), 351-362.

Ikhsan, M. I., Niswaty, R., Saleh, S., \& Arhas, S. H. (2019). The Effectiveness of Using the Lecture Method at SMK Negeri 1 Parepare. PINISI Discretion Review, 3(2), 151-156.

Rahmawati, F. D., Idris, \& Sukamto. (2020). Peranan orang tua terhadap anak dropout (Studi Kasus Pada Jenjang SMP di Tulungagung). Jurnal Sandhyakala, 1(2), 44-55.

Saleh, S., Arhas, S. H., Haerul, H., \& Nasaruddin, N. (2019). Utilization of Learning Media in Digital Simulation Subjects. Jurnal Office, 4(2), 79-90.

Saleh, S., Jamaluddin, J., \& Arhas, S. H. (2019). IbM Supervisi Akademik Kepala Sekolah Dasar Berbasis Information Teknologi di Kecamatan Ulaweng Kabupaten Bone. Humanis, 18(2), 23-28.

Searcy, C., Dixon, S. M., \& Neumann, W. P. (2016). The use of work environment performance indicators in corporate social responsibility reporting. Journal of Cleaner Production, 112, 2907-2921. https://doi.org/https://doi.org/10.1016/j.jclepro.2015.10.081

Sirait, E. J. M., Arhas, S. H., \& Suprianto, S. (2019). The Influence of Assignment of Lecturers at School (ALS) Program on Students Learning Motivation in Tarakan City. Jurnal Ad'ministrare, 6(1), 79-88.

Sparkes, J. R., \& Miyake, M. (2000). Knowledge transfer and human resource development practices: Japanese firms in Brazil and Mexico. International Business Review, 9(5), 599612. https://doi.org/https://doi.org/10.1016/S0969-5931(00)00021-4

Sugiman. (2018). Pemerintahan Desa. Binamulia Hukum, 7(1), 82-95. https://doi.org/10.37893/jbh.v7i1.16

Sugiyono. (2017). Pendekatan Kuantitatif, Kualitatif, Kombinasi, $R \& D$ dan Penelitian Evaluasi. Alfa Beta.

Sung, E. (2017). The influence of visualization tendency on problem-solving ability and learning achievement of primary school students in South Korea. Thinking Skills and Creativity, 26, 168-175. https://doi.org/https://doi.org/10.1016/j.tsc.2017.10.007

Undang-Undang Nomor 6 Tahun 2014 tentang Desa.

Wang, S., Xie, Z., \& Wu, R. (2020). Examining the effects of education level inequality on energy consumption: Evidence from Guangdong Province. Journal of Environmental Management, 269, 110761. https://doi.org/https://doi.org/10.1016/j.jenvman.2020.110761 